\title{
Signals from seabirds indicate changing biology of capelin stocks
}

\author{
Gail K. Davoren*, William A. Montevecchi \\ Biopsychology Programme, Departments of Biology and Psychology, Memorial University, St. John's, \\ Newfoundland A1B 3X9, Canada
}

\begin{abstract}
Key forage species lie at the core of complex marine food webs, providing essential linkages among trophic levels. We examined the interactions of an important forage and commercial fish, capelin Mallotus villosus, and its primary avian predator, the common murre Uria aalge, in the NW Atlantic. Murres are capelin specialists and robust samplers of capelin biology. During the 1990s, the coldest surface-water event in the past 50 to 100 yr occurred in the NW Atlantic (1991), and the eastern Canadian ground-fishery was closed (1992). Concordantly, the biology and behaviour of capelin has undergone very substantial changes. We examined parental food deliveries and production at the world's largest common murre colony on Funk Island off the northeast coast of Newfoundland throughout the 1990s. Murres delayed breeding and delivered smaller and lower quality capelin to their chicks. These changes, corroborated with independent fisheries data, resulted in poor condition of murre chicks, indicating significant effects of changing capelin demographics at higher trophic levels. The diets of the murre chicks indicate that the composition of the capelin population has shifted from high size diversity to mainly smaller capelin. We hypothesize that this change resulted from the elimination of the larger-sized and earlier-spawning genotype and that the NW Atlantic capelin population is exhibiting signs of reduced reproductive potential that likely reflects lower spawning biomass.
\end{abstract}

KEY WORDS: Predator-prey interaction - Bio-indicator - Ecosystem dynamics · Common murre · Uria aalge $\cdot$ Capelin $\cdot$ Mallotus villosus

\section{INTRODUCTION}

Multi-species interactions occur over multiple spatial and temporal biophysical scales (Hunt \& Schneider 1987) and generate complex food-web dynamics (Pimm 1982). Top predators integrate, buffer and reflect ecosystem dynamics through their behaviour and life history patterns (May et al. 1979, Aebischer et al. 1990, Ainley et al. 1996). In marine ecosystems, key forage species lie at the core of this complexity, providing essential linkages for energy transfer from lower trophic levels, involving plankton, to large vertebrates (Lavigne 1996). Within this context, we examined predator-prey interactions during a period of rapid biophysical change in the NW Atlantic (e.g. Montevecchi \& Myers 1996, 1997).
Major ecosystem-level oceanographic and humaninduced perturbations were pervasive in the NW Atlantic during the 1990s. Specifically, the coldest water event during the past 50 to $100 \mathrm{yr}$ occurred during 1991 (Drinkwater 1996) and the eastern Canadian ground-fishery was closed during 1992 (Hutchings 2000). These events produced unexpected shifts in multi-species interactions (e.g. Carscadden et al. 2002), many of which were mediated through dramatic changes in the biology and behaviour of capelin Mallotus villosus during the 1990s. Capelin is a keystone forage fish species in most northern marine ecosystems and is the primary prey of the large vertebrate food web in the NW Atlantic, including ground fish, seals, whales and birds (Lavigne 1996, Montevecchi 2001). Changes in capelin biology during the 1990s included 
delayed spawning by 4 to $6 \mathrm{wk}$, more protracted spawning periods, southward distributional shifts, and younger age at spawning (Carscadden \& Nakashima 1997, Frank et al. 1996).

Evidence from seabirds has been used to assess prey and ecosystem conditions (Cairns 1987, Hatch et al. 1993) over multiple spatial and temporal scales (Montevecchi \& Myers 1995, 1996, 1997). Initial indications that birds were responding to the ecosystem-level perturbations in the NW Atlantic included striking shifts in the diets of northern gannets Sula bassana (Montevecchi \& Myers 1995, 1996) that have persisted throughout the 1990s. The ground fishery closure intensified the effects of changes in capelin biology for some seabirds by removing massive tonnages of discards and offal from offshore and inshore waters. This food limitation of surface-feeding and scavenging Larus gulls resulted in intense predation pressure on other smaller seabirds, primarily black-legged kittiwakes (Regehr \& Montevecchi 1997), Atlantic puffins (Russell \& Montevecchi 1996) and Leach's storm petrels (Stenhouse \& Montevecchi 1999).

Common murres Uria aalge are potentially excellent samplers of capelin biology because they specialize in preying on capelin and are the primary avian predator

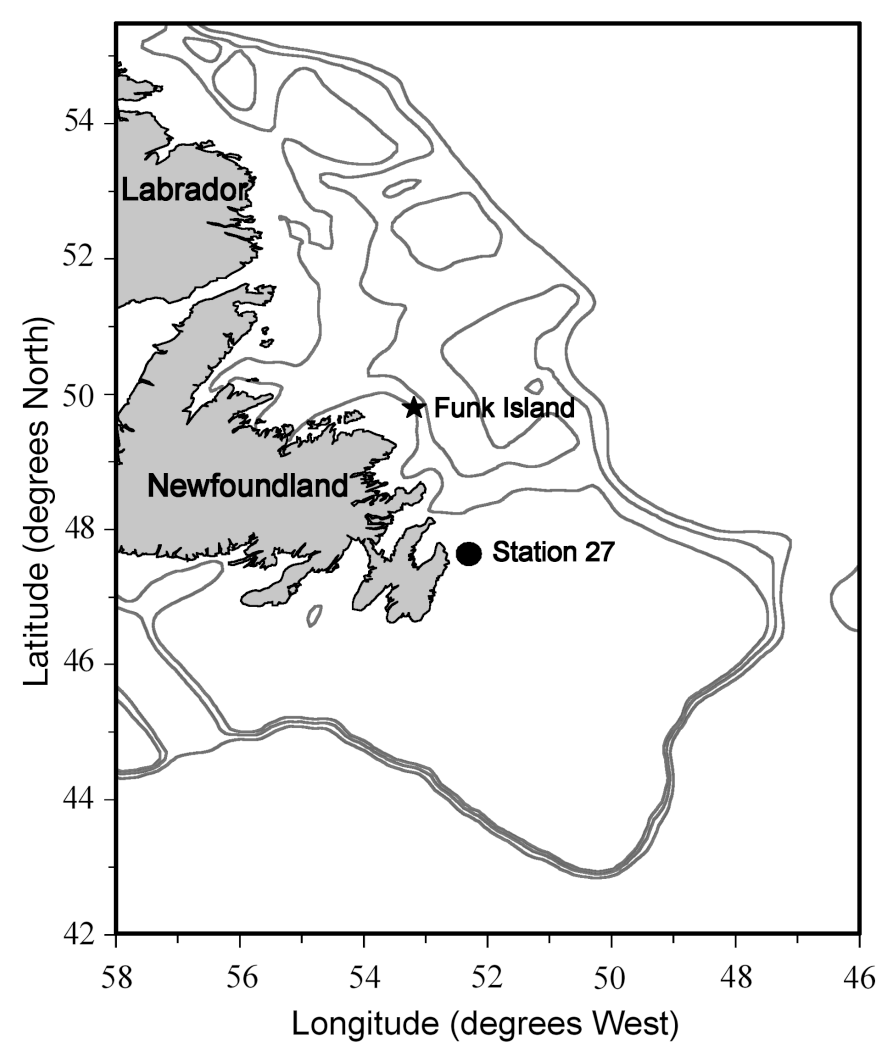

Fig. 1. Map of study area showing Funk Island Seabird Ecological Reserve $(\star)$ and hydrographic Stn $27(\bullet)$. Depth contours are 200, 300 and $500 \mathrm{~m}$ of capelin in the NW Atlantic (Montevecchi 2000). The common murre is a long-lived, pursuit-diving marine bird that breeds in large, dense colonies. Historically in Newfoundland, murres return to colonies during May to secure nest sites. One egg is laid during early June and is incubated for 1 mo. For 3 wk after hatching, parents rear a single chick, to which they deliver 1 fish after each foraging trip at the colony, providing ca. 4 fish $\mathrm{d}^{-1}$ (Davoren \& Montevecchi 2003). Finally, chicks leave the colony in late July at ca. $25 \%$ of adult body size (Gaston \& Nettleship 1981).

Hatching of seabird chicks in Newfoundland generally coincides with the initial inshore movements of maturing schools of capelin (Cairns et al. 1987, Carscadden et al. 2002). Capelin overwinter in offshore feeding areas near the edge of the continental shelf off Newfoundland. They undergo extensive migrations inshore during the spring to spawn on or near coastal beaches (Carscadden et al. 1989), with larger, older capelin generally arriving inshore followed by smaller, younger fish (Templeman 1948, Carscadden et al. 1997). Inshore migration is initiated once gonads begin to develop and, thus, the timing of inshore migration is mediated through ocean temperature as it regulates growth and maturation rates in offshore areas (Shackell et al. 1994, Carscadden et al. 1997). Therefore, inshore migration is delayed in cold years when maturation rates are slow compared to warmer years (Shackell et al. 1994). Prior to the coldwater event during 1991, capelin spawned on beaches in late June, but throughout the 1990s capelin spawned during July and August, approximately 1 mo later (Carscadden \& Nakashima 1997).

In this paper we analyze a $10 \mathrm{yr}$ data series of breeding times, diets and condition of common murres at the largest colony of common mures in eastern North America, Funk Island, in the NW Atlantic (Montevecchi \& Tuck 1987). We compare these data with other biological and physical indices and use these comparisons to assess the status of capelin in the NW Atlantic.

\section{MATERIALS AND METHODS}

Study area and study design. This study was conducted at the Funk Island Seabird Ecological Reserve $\left(49^{\circ} 45^{\prime} \mathrm{N}, 53^{\circ} 11^{\prime} \mathrm{W}\right)$, which lies approximately $60 \mathrm{~km}$ off the east coast of Newfoundland (Fig. 1). A diversity of 9 seabird species breed on Funk Island, the majority consisting of common murres (340 000 to 400000 breeding pairs; bp), northern gannets ( 10000 bp) and Atlantic puffins (2000 bp; Cairns et al. 1989, Chardine 2000). Common murres represent $\sim 92 \%$ of the breeding bird biomass (Davoren \& Montevecchi 2003), and the murre population appears to be stable (Canadian 
Wildlife Service unpubl. data). The general study design consisted of a temporally fixed 2 wk trip every year in early August to Funk Island (Table 1), where the diets of chicks and the wing length and mass of chicks of a variety of breeding seabird species were measured. In this study we report on a single species, the common murre.

Ocean temperature. Mean annual temperature anomalies from the inception of hydrographic Stn 27 (47 $31^{\prime} 50^{\prime \prime} \mathrm{N}$, $52^{\circ} 35^{\prime} 10^{\prime \prime}$ W) from 1950 to 2000 , integrated over the depth range at the station $(0$ to $175 \mathrm{~m})$, were obtained from Fisheries and Oceans Canada. Annual anomalies were calculated by subtracting the mean annual temperature from the mean over all $55 \mathrm{yr}$ (e.g. a positive anomaly in a given year represents a warmer-than-average water temperature over all years). Stn 27 is situated $17 \mathrm{~km}$ east of St. John's, Newfoundland in the Avalon Channel branch of the Labrador Current, and is approximately $250 \mathrm{~km}$ south of Funk Island (Fig. 1). The hydrographic measurements obtained at this station provide robust indices for oceanographic conditions of the Labrador Current, which dominates the entire Newfoundland and Labrador Shelf (Petrie et al. 1988, Drinkwater 1996). Ocean temperature was used to assess the thermal habitat available to capelin.

Murre abundance at Funk Island. Order of magnitude numbers of breeding murres with chicks present at Funk Island in early August were estimated from 1980 to 2000 . These estimates were made upon arrival at the colony, by rough estimation of the aerial extent of dense concentrations of breeding murres and chicks (Table 1).

Dietary and chick measurements. Capelin delivered to chicks on Funk Island were collected from fishcarrying adults captured with pole nets during early August of 1991 and 2000 (Table 1). The species, sex, maturity (gravid, spent-immature; spent and immature capelin could not always be distinguished, so were pooled in a single category), total length $(\mathrm{cm})$ and mass (g) of each fish were identified and measured. Parental murres were always captured at the same sites, and chicks were measured at the same sub-colony among years by the same researchers (Table 1). Mass was measured to the nearest $1 \mathrm{~g}$ using a $300 \mathrm{~g}$ Pesola spring balance. Flattened wing lengths were measured to the nearest $1 \mathrm{~mm}$.

Data analysis. Because it is a good descriptor of capelin condition (Carscadden \& Frank 2002), we calculated Fulton's K (mass in $\mathrm{g}$ divided by length in $\mathrm{cm}^{3}$ $\times 1000$ ). The condition of murre chicks was calculated by dividing body mass by wing length (Davoren \& Montevecchi 2003). Preliminary analyses revealed a positive linear relationship between wing length and body mass in chicks (slope $\mathrm{b}=2.920, \mathrm{r}=0.833, \mathrm{n}=226$, $\mathrm{p}<0.0001$ ), also making this a robust condition index. Trends in the percent composition of prey items by number in diets throughout the 1990s were assessed using binary logistic regression (maximum likelihood method, G-test; Sokal \& Rohlf 1995) with the independent variables being year and ocean temperature anomaly. The size and condition of capelin and murres were assessed using linear regression, weighted by the inverse variance of the dependent variable, with the independent variables being year and ocean temperature anomaly. Analyses were re-run excluding data from 1991 to determine the impact this anomalous year had on the results.

To simplify the relationship between the percentage of gravid capelin and declining fish size in chick diets, the expected energy delivered to chicks per parental foraging trip was calculated for each year. The mean masses of gravid $\left(X_{\mathrm{g}}\right)$ and spent-immature $\left(X_{\mathrm{s}}\right)$ capelin delivered were calculated for each year; these masses were multiplied by the energy densities of gravid $\left(D_{\mathrm{g}}\right)$ and spent-immature $\left(D_{\mathrm{s}}\right)$ capelin (Montevecchi \& Piatt 1984) and by their proportions (gravid: $p_{\text {gi }}$ spentimmature: $1-p_{\mathrm{g}}$ ) in the diet. Values for gravid and spent-immature capelin were summed to estimate the mean expected energy delivery to a chick after a foraging trip $\left(E_{\text {expected }}\right)$ in each year:

$$
E_{\text {expected }}=\left(X_{\mathrm{g}} \times D_{\mathrm{g}} \times p_{\mathrm{g}}\right)+\left(X_{\mathrm{s}} \times D_{\mathrm{s}} \times\left[1-p_{\mathrm{g}}\right]\right)
$$

Trends in the expected amount of energy delivered to a chick were assessed using linear regression with year and ocean temperature anomaly as independent variables. 


\section{RESULTS}

The ocean climate in the Newfoundland and Labrador region has generally cooled since the midlate 1980s, reaching a historical minimum in 1991 but has since then steadily increased (Fig. 2; Drinkwater 1996). Therefore, during the study period (1991 to 2000), the mean ocean temperature anomalies at Stn 27 increased significantly (Table 2). This relationship was not significant when 1991 was removed (Table 2), indicating the magnitude of this cold-water perturbation on the warming trend in Newfoundland through the 1990 s.

Two years after the cold-water event in 1991, the number of breeding murres with chicks at Funk Island increased dramatically and remained high throughout the study period (Fig. 3). It is important to note that this increase during 1993 was very obvious, in that our temporally fixed trips to Funk Island provided little opportunity to study murres prior to 1990 because almost all murres had left the colony before our arrival in early August. Since 1993, however, there have been high numbers of breeding murres with chicks each year during our trip.

A total of 1419 fish delivered to murre chicks were collected over the study period, 1334 (94\%) of which were capelin. In each year, almost all fish fed to murre chicks were capelin (74 to 99\% annual averages), specifically female capelin (81 to $100 \%$ ); percentages did not vary significantly among years (percent capelin in diet: $G=0.89, \mathrm{df}=1, \mathrm{p}=0.345$; percent female capelin in diet: $G=1.194$, $\mathrm{df}=1, \mathrm{p}=0.27$ ). The percentages of mature female or gravid capelin delivered to chicks (6 to $83 \%$ ), however, decreased through the 1990s ( $G=152.65$, df $=1, p<0.0001$; Fig. 4a). This trend was consistent when data from 1991 were excluded $(G=192.32$, df $=1, \mathrm{p}<0.0001)$ and also decreased with increasing ocean temperature when 1991 was included $(G=198.06, \mathrm{df}=1, \mathrm{p}<0.0001)$ and excluded ( $G=289.29$, df $=1, \mathrm{p}<0.0001)$.

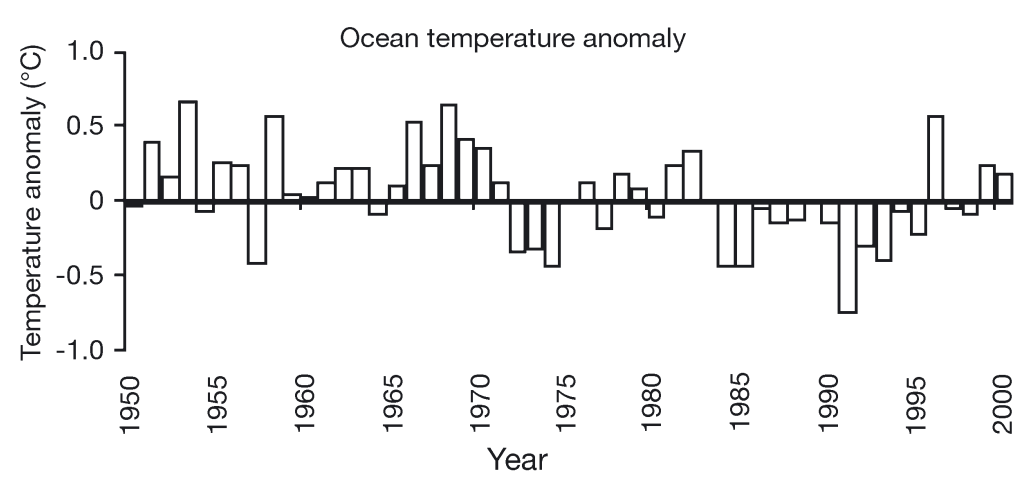

Fig. 2. Mean annual temperature anomalies from 1950 to 2000, integrated from 0 to $175 \mathrm{~m}$, at hydrographic Stn 27
The size (length and mass) of all female capelin delivered to murres tended to decline throughout the 1990 s, contributing to a significant decline in the condition of female capelin (Table 2, Fig. 4b). Female mass and condition declined significantly with increasing ocean temperature but the trend for mass was not significant when data from 1991 were excluded. The length and mass of gravid capelin declined significantly throughout the 1990s though condition did not. In contrast, the length and mass of gravid capelin did not vary significantly with ocean temperature, whereas condition increased significantly with increasing temperature. The size and condition of spent-immature capelin declined throughout the 1990s, but these trends were not significant. The relationship between ocean temperature and the size and condition of spentimmature capelin was negative but nonsignificant, and these trends reversed when data from 1991 were excluded. Overall, the length, mass and condition of female capelin delivered to murre chicks tended to decline throughout the $1990 \mathrm{~s}$, and these trends were observed when data from the oceanographically anomalous 1991 were excluded, indicating that these declines did not occur solely due to data in 1991 (Table 2). Due to the positive relationship between year and ocean temperature throughout the study period, the condition of female capelin tended to decline with increasing ocean temperature, but these trends became variable when data from 1991 were excluded (Table 2).

To test whether inter-annual dietary variation altered offspring provisioning, the energy per fish delivery was estimated by combining mean fish mass, energy density values and proportions of capelin types in the diet. Energy per fish delivered to murre chicks declined significantly through the 1990s (Fig. 4c) and, consequently, with increasing ocean temperature (Table 2).

A total of 226 chicks were measured over the study period. Chick condition declined significantly throughout the 1990s (Fig. 4d), due to declining body mass and increasing wing length (Table 2). The decline in chick condition throughout the 1990s was not significant when the data from 1991 were excluded. The relationship between the energy per fish delivered and chick condition was positive but nonsignificant ( $\mathrm{b}=0.018, \mathrm{r}=0.594$, $\mathrm{n}=7, \mathrm{p}=0.160$ ). The mass of murre chicks declined with increasing water temperature, while wing length increased but neither trend was significant. Chick condition declined with increasing ocean temperature, but this was only significant when data from 1991 were excluded. Overall, the energy de- 
Table 2. Uria aalge and Mallotus villosus. Statistical results of linear regressions examining the relationship between independent variables (Year, and mean ocean temperature anomaly; Temperature) and length $(\mathrm{cm})$, mass $(\mathrm{g})$ and $\mathrm{condition}\left(\mathrm{g} \mathrm{cm}^{-3}\right)$ of capelin; the energy $(\mathrm{kJ})$ delivered to chicks of common murres per capelin; and the wing length (mm), mass $(\mathrm{g})$ and condition $\left(\mathrm{g} \mathrm{mm}^{-1}\right)$ of chicks of common murres both throughout the entire study period (1991-2000) and excluding the anomalous coldwater year of 1991 (1992-2000). Sample sizes (n), slopes of the regression line (b), regression coefficients (r) and p-values are given. Bold entries indicate statistically significant relationships

\begin{tabular}{|c|c|c|c|c|c|c|c|c|}
\hline \multirow{2}{*}{$\begin{array}{l}\text { Independent and } \\
\text { dependent variables }\end{array}$} & \multicolumn{4}{|c|}{ - 1991-2000 } & \multicolumn{4}{|c|}{ - 1992-2000 } \\
\hline & $\mathrm{n}$ & $\mathrm{b}$ & r & $\mathrm{p}$ & $\mathrm{n}$ & $\mathrm{b}$ & $\mathrm{r}$ & $\mathrm{p}$ \\
\hline \multicolumn{9}{|l|}{ Year versus: } \\
\hline Temperature: & 10 & 0.084 & 0.731 & 0.016 & 9 & 0.047 & 0.606 & 0.184 \\
\hline \multicolumn{9}{|l|}{ Year versus } \\
\hline Female capelin length & 10 & -0.070 & 0.297 & 0.404 & 9 & 0.010 & 0.051 & 0.897 \\
\hline Female capelin mass & 10 & -0.305 & 0.550 & 0.099 & 9 & -0.153 & 0.401 & 0.285 \\
\hline Female capelin condition & 10 & -0.089 & 0.708 & 0.022 & 9 & -0.099 & 0.728 & 0.026 \\
\hline Gravid capelin length & 10 & -0.224 & 0.769 & 0.009 & 9 & -0.142 & 0.644 & 0.061 \\
\hline Gravid capelin mass & 10 & -0.620 & 0.650 & 0.042 & 9 & -0.245 & 0.462 & 0.211 \\
\hline Gravid capelin condition & 10 & 0.082 & 0.530 & 0.115 & 9 & 0.095 & 0.545 & 0.129 \\
\hline Spent-immature capelin length & 10 & -0.092 & 0.306 & 0.389 & 9 & -0.054 & 0.172 & 0.658 \\
\hline Spent-immature capelin mass & 10 & -0.051 & 0.087 & 0.810 & 9 & 0.108 & 0.188 & 0.628 \\
\hline Spent-immature capelin condition & 10 & -0.107 & 0.273 & 0.445 & 9 & 0.043 & 0.402 & 0.283 \\
\hline Energy delivered per fish & 10 & -1.804 & 0.748 & 0.013 & 9 & -1.338 & 0.668 & 0.049 \\
\hline Murre chick-wing length & 7 & 0.382 & 0.296 & 0.520 & 6 & 0.775 & 0.478 & 0.338 \\
\hline Murre chick mass & 7 & -2.079 & 0.509 & 0.244 & 6 & -1.228 & 0.275 & 0.597 \\
\hline Murre chick condition & 7 & -0.094 & 0.763 & 0.046 & 6 & -0.084 & 0.674 & 0.142 \\
\hline \multicolumn{9}{|l|}{ Temperature (1991-2000) versus: } \\
\hline Female capelin length & 10 & -0.184 & 0.115 & 0.752 & 9 & 0.573 & 0.404 & 0.281 \\
\hline Female capelin mass & 10 & -2.729 & 0.697 & 0.025 & 9 & -1.682 & 0.611 & 0.080 \\
\hline Female capelin condition & 10 & -0.744 & 0.675 & 0.032 & 9 & -1.077 & 0.875 & 0.002 \\
\hline Gravid capelin length & 10 & -0.832 & 0.369 & 0.294 & 9 & 0.380 & 0.214 & 0.581 \\
\hline Gravid capelin mass & 10 & -0.876 & 0.459 & 0.182 & 9 & 0.113 & 0.032 & 0.935 \\
\hline Gravid capelin condition & 10 & 0.870 & 0.712 & 0.021 & 9 & 1.141 & 0.786 & 0.012 \\
\hline Spent-immature capelin length & 10 & -0.120 & 0.057 & 0.875 & 9 & 0.348 & 0.154 & 0.692 \\
\hline Spent-immature capelin mass & 10 & -0.459 & 0.101 & 0.781 & 9 & 1.158 & 0.248 & 0.520 \\
\hline Spent-immature capelin condition & 10 & -0.024 & 0.030 & 0.935 & 9 & 0.030 & 0.032 & 0.934 \\
\hline Energy delivered per fish & 10 & -20.084 & 0.870 & 0.001 & 9 & -16.241 & 0.813 & 0.008 \\
\hline Murre chick-wing length & 7 & 1.583 & 0.117 & 0.803 & 6 & 14.481 & 0.499 & 0.314 \\
\hline Murre chick mass & 7 & -30.351 & 0.655 & 0.110 & 6 & -40.028 & 0.483 & 0.331 \\
\hline Murre chick condition & 7 & -0.999 & 0.728 & 0.064 & 6 & -2.148 & 0.844 & 0.035 \\
\hline
\end{tabular}

livered per fish declined significantly throughout the 1990s, concurrent with a significant decline in the condition (mass at a specific wing length) of murre chicks.

\section{DISCUSSION}

\section{Murre abundance at Funk Island}

The cold-water perturbation during 1991 (Drinkwater 1996) resulted in a 4 to 6 wk delay in the inshore migration and spawning of capelin (Carscadden \& Nakashima 1997). The breeding population of murres at Funk Island was stable throughout the study period (Canadian Wildlife Service unpubl. data), and the increase in the abundance of breeding murres with chicks at Funk Island observed in early August 1993 resulted from a delay in the timing of breeding. Murres

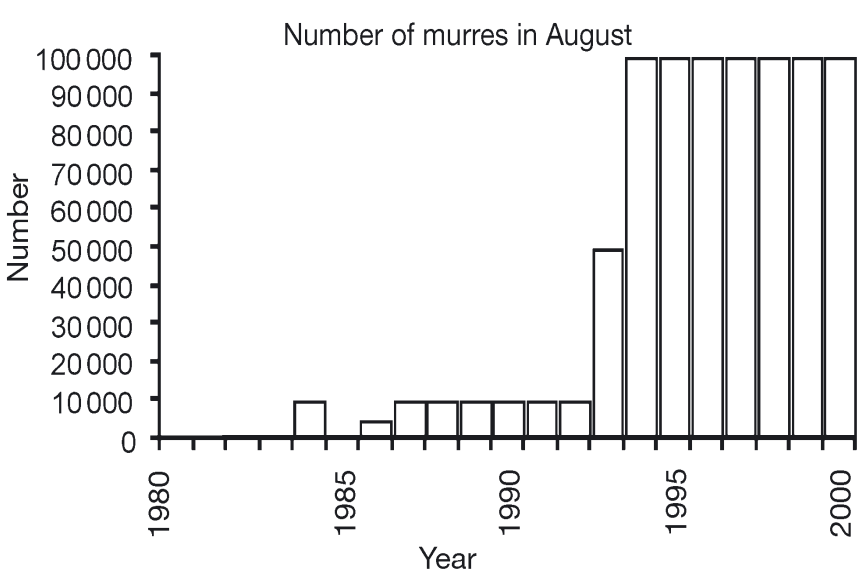

Fig. 3. Uria aalge. Order of magnitude numbers of breeding common murres present at Funk Island in early August from 1980 to 2000 


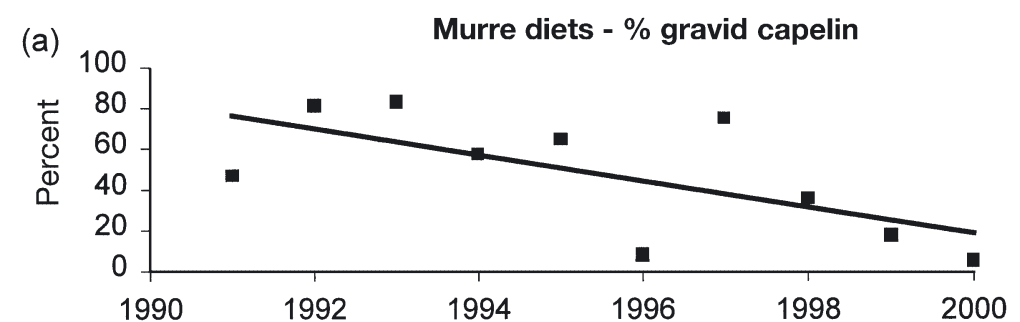

(b)
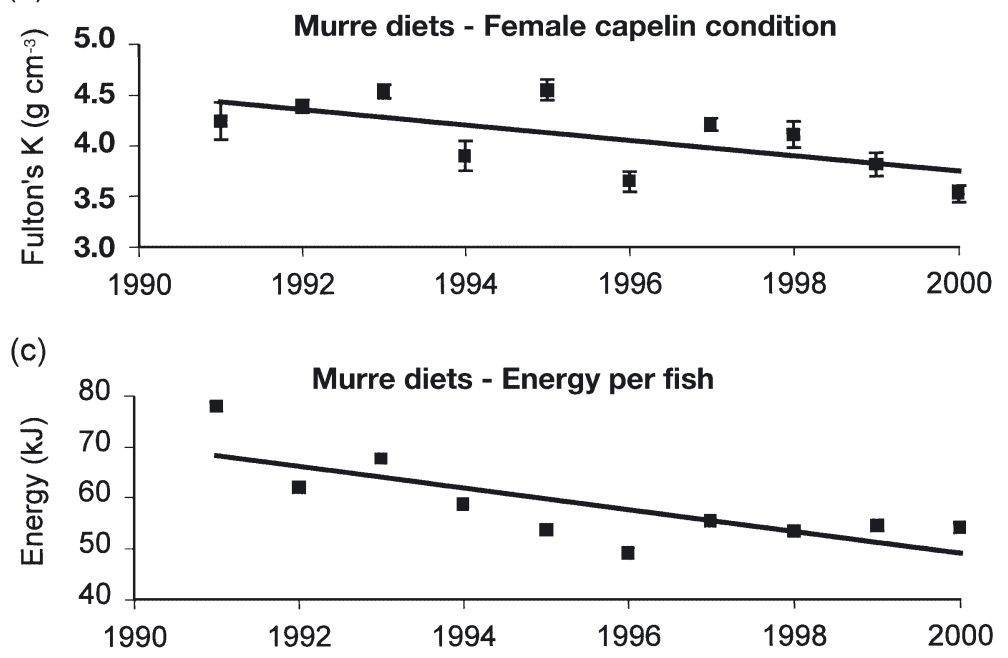

(d)

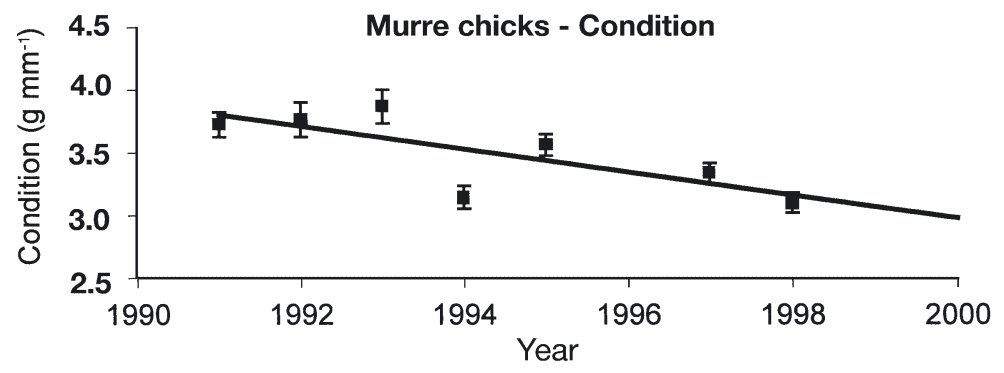

Fig. 4. Uria aalge and Mallotus villosus. Relationship of year (1990 to 2000) with (a) \% of gravid capelin by number in the diets of common murres, (b) condition (Fulton's K) of female capelin in the diets of murres, (c) mean expected energy delivered per capelin and (d) condition of murre chicks at Funk Island

likely delayed breeding in response to the delayed inshore migration of capelin to maximize the temporal match between the availability of capelin within foraging ranges and the hatching of chicks (Cairns et al. 1987, Bertram et al. 2001, Carscadden et al. 2002). It is also possible that murres increased the duration of chick-rearing, but this could not solely account for such a large increase in the number of breeding murres and chicks at the colony in early August. Murres did not appear to delay breeding due to delayed capelin migration in 1991 and 1992, suggesting that they do not have a mechanism through which they can forecast the timing of capelin spawning in any given year (e.g. cold water, low zooplankton density). Consequently, they likely must go through a learning period once prey conditions change.

\section{Diet of murre chicks}

The species composition of fish delivered to chicks did not change throughout the study period but the percentage of gravid capelin declined. Gravid capelin are likely preferred prey due to their higher energy densities relative to spent-immature capelin (Montevecchi \& Piatt 1984). Therefore, we hypothesize that chick diets reflect the availability of gravid capelin within foraging ranges from Funk Island, and the proportion of gravid capelin delivered to murre chicks depends on the timing of capelin spawning relative to the chick-rearing period. Despite delayed breeding, parental murres were unable to maximize the temporal overlap of chick-rearing with the arrival of gravid capelin. This mismatch could be due to the influence of ocean temperature on annual spawning times of capelin throughout the 1990s (Carscadden \& Nakashima 1997, Carscadden et al. 1997), also indicated by the higher percentage of gravid capelin in the diets of murre chicks during colder years. Overall, the variability in the percentage of gravid capelin delivered to murre chicks is consistent with the increased irregularity in the timing of major spawning events of capelin, as well as the protracted spawning period throughout the 1990s (Nakashima 1996, Carscadden \& Nakashima 1997).

The length, mass and condition of female capelin delivered to chicks throughout the 1990s declined as ocean temperature increased. This finding is counterintuitive because higher growth would be expected under warm water conditions. Historically, large capelin arrived inshore prior to smaller capelin (Templeman 1948) and, thus, the availability of large capelin around Funk Island might be reduced in warmer years because they had spawned early in relation to chickrearing by murres. The trend of large fish arriving prior to small ones, however, deteriorated during the 1990s (Nakashima 1996). Declining trends in the size and condition of capelin delivered to murre chicks through the 1990s were corroborated independently by Fisheries and Oceans Canada data on spawning 
and juvenile capelin (Carscadden \& Nakashima 1997, Anderson et al. 2001, Carscadden \& Frank 2002). This indicates that factors other than simply ocean temperature (e.g. low zooplankton biomass in the 1990s) are responsible for these declines in capelin size and condition (Carscadden \& Frank 2002).

\section{Chick condition}

The changing biology and behaviour of capelin throughout the 1990s resulted in a substantial decline in the energy delivered per capelin to murre chicks. This dietary change was concurrent with a decline in chick condition, generally due to declining body mass $\left(\sim 2 \mathrm{~g} \mathrm{yr}^{-1}\right)$. Unexpectedly, the wing length of murre chicks tended to increase through the study period, whereas chicks measured at a fixed time should have been younger with shorter wings if the timing of breeding was delayed. Shorter wing lengths at age, however, are dependent on a linear relationship between wing length and chick age. Alternately, chicks may differentially allocate energy to wing versus mass growth under variable foraging conditions (Oyan \& Anker-Nilssen 1996, Rodway 1997). For instance, murre chicks allocate more energy to wing growth when provisioning rates are low (Wilhelm \& Storey unpubl. data), suggesting that study chicks at Funk Island may have allocated more energy to wing growth as the energy delivered per fish declined. Other possibilities for the increase in wing growth are an extended chick-rearing period in the late 1990s or older chicks departing the colony before measurements in the early 1990s.

Regardless of the mechanism, our results clearly indicate that the body mass of chicks at specific wing lengths declined throughout the 1990s. If chicks were unable to attain adequate body masses prior to colony departure or after departure at sea, one would expect lower survival and recruitment into the breeding population. Population trends available for colonies of common murres in Newfoundland suggest that the most colonies are increasing; however, the Funk Island colony appears to be stable (Canadian Wildlife Service unpubl. data). Provisioning rates, breeding success and fledgling condition were lower at this colony compared to others (Davoren \& Montevecchi 2003, Davoren et al. 2003). These comparisons suggest that the Funk Island colony is at carrying capacity, is a source population for other colonies, or that fledgling survival is not high enough to generate population growth. If the latter is true, a lower potential for colony growth at Funk Island could impact the entire NW Atlantic population of murres, as $75 \%$ of the population breeds on this island (Cairns et al. 1989).

\section{Ecosystem-level responses}

Consistent among all data sources, including signals from murres shown here, are declines in capelin condition and size and delays in spawning times throughout the 1990s. Declining size is attributable to smaller $3 \mathrm{yr}$ old fish and to significantly higher proportions of $2 \mathrm{yr}$ old capelin spawning (Nakashima 1996, Carscadden et al. 1997). Before 1990, mainly larger 3 and $4 \mathrm{yr}$ old capelin spawned (Anonymous 2001). Integration of this information with widely divergent biomass estimates of capelin throughout the 1990s has led to conflicting statements on current stock status (Carscadden et al. 2001, Rose 2001). These sudden changes were initially associated with the significant oceanographic perturbation in 1991 (Drinkwater 1996). However, physical environmental conditions have since returned to pre-perturbation levels but biological responses have not. Trends in size and spawning times of capelin and the continued delayed breeding of murres remain mismatched under warm oceanographic conditions. These large-scale biological patterns, apparently precipitated by a physical forcing in the early 1990s, are consistent with a regime shift (Cushing 1982, Steele 1998) in the NW Atlantic (Montevecchi \& Myers 1996), suggesting that global climate change is having pervasive ecosystem-level effects.

The oceanographic event of 1991 coincided with a marked reduction in older, larger and early spawning capelin (Carscadden \& Nakashima 1997). Increased natural mortality of adult fish, larvae and eggs also was suggested for other species at this time (Bundy 2001). The inshore fishery for capelin targets older and larger gravid capelin that arrive first at spawning beaches (Carscadden \& Nakashima 1997). This fishery has had low quotas since the late 1970s (Carscadden \& Frank 2002) but high fishing mortality in the mid-1970s could have influenced the size and age structure of the population (Barot et al. 2002). Regardless of the mechanism, the loss of larger fish may have resulted in a population now composed of smaller, younger and later spawning fish (Therriault et al. 1996). Younger age at maturity within fish stocks can be caused by environmental factors (e.g. water temperature), population density (compensatory response) and/or genotype frequency, assuming that age of maturity is a heritable life-history trait (genetic selection; Trippel 1995, Law 2002). The changes in capelin biology are not consistent with environmental factors or densitydependent responses, because environmental conditions have returned to pre-perturbation levels and because spawning capelin are both smaller and younger. We hypothesize, therefore, that the current capelin population in eastern Newfoundland consists of a lower proportion of the larger and earlier-spawning 
genotypes. A reduction in the proportion of larger, more fecund individuals combined with the poor condition of remaining female fish will decrease population egg production and egg viability and subsequent recruitment (Trippel 1995, Scott et al. 1999). In view of these circumstances, we further contend that the capelin population in the NW Atlantic is exhibiting signs of reduced reproductive potential that likely reflects lower spawning biomass (Rose 2001, cf. Carscadden et al. 2001).

\section{CONCLUSIONS}

Overall, independent evidence corroborates that murres are sensitive samplers of inter-annual variation in female capelin condition, timing of inshore spawning and availability of gravid capelin. Even though murres sample prey on a meso-scale (1 to $100 \mathrm{~km}$ ) around colonies, changes in murre chick diet reflected large-scale (>100 km) changes in capelin biology and behaviour (see also Montevecchi \& Myers 1995, 1996, 1997). Shifts in capelin biology were also reflected in the murres' breeding biology, indicating significant effects at higher trophic levels.

Comprehensive scientific assessments of capelin biomass are no longer carried out in eastern Canada (Anonymous 2001), so the current status of the capelin stock in the NW Atlantic is unknown. Yet, an inshore fishery directed at the early spawning, large gravid female capelin is still actively prosecuted in Newfoundland. The annual allowable catch is set at $10 \%$ of the total biomass (Shelton et al. 1993). Without accurate biomass estimates, however, this management approach is difficult to justify biologically. Prospects for the recovery of cod in eastern Canada depend on capelin stocks (Rose 2001), of which cod have been estimated to consume 1 to many millions of tonnes (Bundy et al. 2000). There is a need for precautionary approaches to capelin stock management, especially given the reliance of top predators on capelin in the NW Atlantic (Lavigne 1996, Montevecchi 2001). Clearly, more comprehensive, multi-species, ecosystem research is required to unravel the complex interactions that result in widely divergent estimates of capelin biomass (Carscadden \& Nakashima 1997) and their implications for food web dynamics in the NW Atlantic.

Acknowledgements. We thank I. Stenhouse, J. Russell, S. Garthe, L. Dominguez, D. Cairns, P. Ryan and N. Montevecchi for assistance in the field. We greatly appreciate the advice on statistical analyses from D. Schneider. We thank J. Anderson, F. Mowbray, R. O'Driscoll, G. Rose and J. Hutchings for comments on an earlier version of this manuscript. NSERC Operating and DFO Subvention (W.A.M.) and NSERC post-graduate fellowships (G.K.D.) funded this research.

\section{LITERATURE CITED}

Aebischer NJ, Coulson JC, Colebrook JM (1990) Parallel long term trends across four marine trophic levels and weather. Nature 347:753-755

Ainley DG, Sydeman WJ, Norton J (1996) Upper trophic level predators indicate interannual negative and positive anomalies in the California Current food web. Mar Ecol Prog Ser 118:69-79

Anderson JT, Dalley E, Davis D (2001) Year-class strength of Northwest Atlantic capelin (2J3KLNO) estimated as 0-group (larval), age one and age two-plus, from the pelagic juvenile fish surveys, 1994-1999. In: Anonymous (ed) Capelin in SA2+Div. 3KL. Canadian Department of Fisheries and Oceans, St. John's, p 211-223

Anonymous (2001) Stock status report capelin in subarea $2+$ Div. 3KL Update. Canadian Stock Assessment Secretariat, Sci Stock Status Rep B2-02. Ottawa

Barot S, Heino M, O'Brien L, Dieckmann U (2002) Reaction norms for age and size at maturation: study of the longterm trend (1970-1998) for Georges Bank and Gulf of Maine cod stocks. ICES CM Y:03

Bertram DF, Mackas DL, McKinnell SM (2001) The seasonal cycle revisited: interannual variation and ecosystem consequences. Prog Oceanogr 49:283-307

Bundy A (2001) Fishing on ecosystems: the interplay of fishing and predation in Newfoundland-Labrador. Can J Fish Aquat Sci 58:1153-1167

Bundy A, Lilly GR, Shelton PA (2000) A mass balance model of the Newfoundland and Labrador Shelf. Can Tech Rep Fish Aquat Sci 2310

Cairns DK (1987) Seabirds as indicators of marine food supplies. Biol Oceanogr 5:261-271

Cairns DK, Bredin KA, Montevecchi WA (1987) Activity budgets and foraging ranges of breeding common murres. Auk 104:218-224

Cairns DK, Montevecchi WA, Threlfall W (1989) Researcher's guide to Newfoundland seabird colonies. Memorial University of Newfoundland, St. John's, Occas Pap Biol No 14, p 1-34

Carscadden JE, Frank KT (2002) Temporal variability in the condition factors of Newfoundland capelin (Mallotus villosus) during the past two decades. ICES J Mar Sci 59: 950-958

Carscadden JE, Nakashima BS (1997) Abundance and changes in distribution, biology and behavior of capelin in response to cooler waters of the 1990s. In: Forage fishes in marine ecosystems. Proc Int Symp Rose of Forage Fishes in Alaska. Sea Grant Program Rep No 97-01, p 457-468, Fairbanks, AL

Carscadden JE, Frank KT, Miller DS (1989) Capelin (Mallotus villosus) spawning on the southeast shoal: influence of physical factors past and present. Can J Fish Aquat Sci 45: $1743-1754$

Carscadden JE, Nakashima BS, Frank KT (1997) Effects of fish length and temperature on the timing of peak spawning in capelin (Mallotus villosus). Can J Fish Aquat Sci 54: $781-787$

Carscadden JE, Frank KT, Leggett WC (2001) Ecosystem changes and the effects on capelin (Mallotus villosus), a major forage species. Can J Fish Aquat Sci 58:73-85.

Carscadden JE, Montevecchi WA, Davoren GK, Nakashima BS (2002) Trophic relationships among capelin (Mallotus villosus) and marine birds in a changing ecosystem. ICES J Mar Sci 59:1027-1033

Chardine JW (2000) Census of northern gannet colonies in the Atlantic region. Can Wildl Serv Atl Reg Tech Rep Ser 361 
Cushing DH (1982) Fisheries and climate. Academic Press, London

Davoren GK, Montevecchi WA (2003) Consequences of foraging trip duration on provisioning behaviour and fledging condition of common murres. J Avian Biol 34:44-53

Davoren GK, Montevecchi WA, Anderson JT (2003) Search strategies of a pursuit-diving marine bird and the persistence of prey patches. Ecol Monogr 73:463-481

Drinkwater KF (1996) Atmospheric and oceanic variability in the northwest Atlantic during the 1980s and early 1990s. J Northwest Atl Fish Sci 18:77-97

Frank KT, Carscadden JE, Simon JE (1996) Recent excursions of capelin (Mallotus villosus) to the Scotian Shelf and Flemish Cap during anomalous hydrographic conditions. Can J Fish Aquat Sci 53:1473-1486

Gaston AJ, Nettleship DN (1981) The thick-billed murres of Prince Leopold Island: a study of the breeding ecology of a colonial high arctic seabird. Can Wildl Serv Monogr Ser 6, Ottawa

Hatch SA, Byrd GV, Irons DB, Hunt GL Jr (1993) Status and ecology of kittiwakes (Rissa tridactyla and $R$. brevirostris) in the North Pacific. In: Vermeer K, Briggs KT, Morgan $\mathrm{KH}$, Siegel-Causey D (eds) The status, ecology and conservation of marine birds in the north Pacific. Canadian Wildlife Service, Ottawa, p 140-153

Hunt GL Jr, Schneider DC (1987) Scale dependent processes in the physical and biological environment. In: Croxall JP (ed) Seabirds: feeding ecology and roles in marine ecosystem. Cambridge University Press, Cambridge, p 7-41

Hutchings JA (2000) Collapse and recovery of marine fishes. Nature 406:882-885

Lavigne DM (1996) Ecological interactions between marine mammals, commercial fisheries and their prey: unraveling the tangled web. In: Montevecchi WA (ed) High-latitude seabirds. 4. Trophic relationships and energetics of endotherms in cold ocean systems. Can Spec Publ Fish Aquat Sci 91:59-71

Law R (2002) Selective fishing and phenotypic evolution: past, present and future. ICES CM Y:11

May RM, Beddington JR, Clark CW, Holt SJ, Laws RM (1979) Management of multispecies fisheries. Science 205: $267-277$

Montevecchi WA (2000) Seabirds. In: Bundy A, Lilly GR, Shelton PA (eds) Bulk biomass model of the Newfoundland Shelf. Can Tech Rep Fish Aquat Sci 2310:15-18

Montevecchi WA (2001) Interactions between fisheries and seabirds. In: Schreiber EA, Burger J (eds) Biology of marine birds. CRC Press, Boca Raton, FL, p 527-557

Montevecchi WA, Myers RA (1995) Prey harvests of seabirds reflect pelagic fish and squid abundance on multiple spatial and temporal scales. Mar Ecol Prog Ser 117:1-9

Montevecchi WA, Myers RA (1996) Dietary changes of seabirds reflect shifts in pelagic food webs. Sarsia 80:313-322

Montevecchi WA, Myers RA (1997) Centurial and decadal oceanographic influences on changes in Northern Gannet populations and diets in the north-west Atlantic: implications for climate change. ICES J Mar Sci 54:608-614

Montevecchi WA, Piatt JF (1984) Composition and energy contents of mature inshore spawning capelin (Mallotus

Editorial responsibility: Otto Kinne (Editor),

Oldendorf/Luhe, Germany villosus): implications for seabird predators. J Comp Biochem Physiol 78:15-20

Montevecchi WA, Tuck LM (1987) Newfoundland birds: exploitation, study, conservation. Nuttall Ornithological Club, Cambridge, MA

Nakashima BS (1996) The relationship between oceanographic conditions in the 1990s and changes in spawning behaviour, growth and early life history of capelin (Mallotus villosus). NAFO Sci Council Studies 24:55-68

Oyan HS, Anker-Nilssen T (1996) Allocation of growth in food-stressed Atlantic puffin chicks. Auk 113:830-841

Petrie B, Akenhead SA, Lazier SA, Loder J (1988) The cold intermediate layer on the Labrador and Northeast Newfoundland Shelves, 1978-86. NAFO Sci Council Studies $12: 57-69$

Pimm SL (1982) Food webs. Chapman \& Hall, New York

Regehr HM, Montevecchi WA (1997) Interactive effects of food shortage and predation on breeding failure of blacklegged kittiwakes: indirect effects of fisheries activities and implications for indicator species. Mar Ecol Prog Ser 155:249-260

Rodway MS (1997) Relationship between wing length and body mass in Atlantic puffin chicks. J Field Ornithol 68: $338-347$

Rose GA (2001) Can Newfoundland cod stocks recover without capelin? ICES Newsletter 38:8

Russell JO, Montevecchi WA (1996) Predation on adult puffins Fratercula arctica by great black-backed gulls Larus marinus at a Newfoundland colony. Ibis 138:791-794

Scott B, Marteinsdottir G, Wright P (1999) Potential effects of maternal factors on spawning stock-recruitment relationships under varying fishing pressure. Can J Fish Aquat Sci 56:1882-1890

Shackell NL, Carscadden JE, Miller DS (1994) Migration of pre-spawning capelin (Mallotus villosus) as related to temperature on the northern Grand Bank, Newfoundland. ICES J Mar Sci 51:107-114

Shelton PA, Carscadden JE, Hoenig JM (1993) Risk evaluation of the $10 \%$ harvest rate procedure for capelin in NAFO Division 3L. In: Smith SJ, Hunt JJ, Rivard D (eds) Risk evaluation and biological reference points for fisheries management. Can Spec Publ Fish Aquat Sci 120: 193-201

Sokal RR, Rohlf FJ (1995) Biometry. WH Freeman, New York Steele JH (1998) Regime shifts in marine ecosystems. Ecol Appl 8:S33-S36

Stenhouse IJ, Montevecchi WA (1999) Indirect effects of the availability of capelin and fishery discards: gull predation on breeding storm-petrels. Mar Ecol Prog Ser 184: 303-307

Templeman W (1948) The life history of the capelin (Mallotus villosus O.F. Muller) in Newfoundland waters. Bull Newfoundland Govern Lab 17:1-151

Therriault TW, Schneider DC, Methven DA (1996) The timing of spawning in capelin (Mallotus villosus Muller) at a coastal location in eastern Newfoundland. Polar Biol 16: 201-207

Trippel EA (1995) Age at maturity as a stress indicator in fisheries. Bioscience 45:759-771

Submitted: November 11, 2002; Accepted: May 21, 2003

Proofs received from author(s): August 12, 2003 